\title{
Cadmium and morphological alterations in the rotifer Philodina cf. roseola (Bdelloidea: Philodinidae) and the worm Aeolosoma hemprichi (Annelida: Aeolosomatidae)
}

\author{
Daniela Pérez-Yañez, Danika Ruth Soriano-Martínez, Mendy Eded Damian-Ku, \\ Eduardo Cejudo-Espinosa \& Jesús Alvarado-Flores* \\ Unidad de Ciencias del Agua, Centro de Investigación Científica de Yucatán A. C. Cancún, Quintana Roo, México. \\ Calle 8, No. 39, Mz. 29, S.M. 64, C.P. 77500; daniela.perez@estudiantes.cicy.mx, mendydamian@gmail.com, \\ danikaruthsm@gmail.com, eduardo.cejudo@cicy.mx, jesus.alvarado@cicy.mx \\ * Correspondence
}

Received 23-I-2019. C Corrected 29-V-2019. Accepted 27-IX-2019.

\begin{abstract}
Cadmium is a toxic metal for zooplankton that produces deformations. It is also considered an environmental hazard to aquatic life. Since it has a significant effect in some marine organisms, we used two native zooplankton species from Quintana Roo, Mexico to obtain data regarding cadmium toxicity including the threshold concentration for observable morphological alterations and the percentage of organisms with morphological alterations at the exposure concentrations. We used the rotifer Philodina cf roseola and the oligochaeta Aeolosoma hemprichi, since both feed from the algae Nannochloropsis oculata. Both animals were exposed to a cadmium concentration range from $0.05 \mathrm{mg} / 1(0.047 \mathrm{mg} / 1$, real concentration) to $10.0 \mathrm{mg} / 1$ (9.39 mg/l, real concentration) for $24 \mathrm{~h}$. The $\mathrm{LC}_{50}$ for cadmium in P. cf roseola was $0.7 \mathrm{mg} / 1$ ( $0.65 \mathrm{mg} / \mathrm{l}$, real concentration), whereas in $A$. hemprichi was $3.38 \mathrm{mg} / 1$ ( $3.17 \mathrm{mg} / 1$, real concentration). The exposure of cadmium at $0.5 \mathrm{mg} / 1(0.47 \mathrm{mg} / 1$, real concentration) for less than $24 \mathrm{~h}$ induced morphological alterations in the lorica of rotifers, foot deformations, and constriction in the middle part of the body. In oligochaetes, damage to the epidermis was noted. The threshold concentration where deformations appeared in rotifer was $0.3 \mathrm{mg} / \mathrm{l}$ at $24 \mathrm{~h}$, while in oligochaeta was $0.5 \mathrm{mg} / 1(0.47 \mathrm{mg} / 1$, real concentration) at $30 \mathrm{~min}$. We concluded that cadmium promotes alterations in aquatic organisms due to direct exposure added to the culture medium.
\end{abstract}

Key words: teratology, ecotoxicology, zooplankton, Yucatan Peninsula, metal toxicity.

Pérez-Yañez, D., Soriano-Martínez, D. R., Damian-Ku, M. E., Cejudo-Espinosa, E., \& Alvarado-Flores, J. (2019). Cadmium and morphological alterations in the rotifer Philodina cf. roseola (Bdelloidea: Philodinidae) and the worm Aeolosoma hemprichi (Annelida: Aeolosomatidae). Revista de Biología Tropical, 67(6), 1406-1417.

Cadmium is present in aquatic ecosystems through both anthropogenic and natural means, but is hazardous to aquatic organisms and human health (ATSDR, 2016). It is one of the most toxic elements to which man is exposed (Bernard, 2008), causing severe adverse effects from chronic exposure. It also ranks seventh on the substance priority list from the Agency for Toxic Substances and Disease Registry (ATSDR, 2016). In general terms, cadmium belongs to the IIB group of the periodic table and has an atomic mass of 112.41. Its ionic form of cadmium $\left(\mathrm{Cd}^{2+}\right)$ is usually combined with oxygen $\left(\mathrm{CdO}_{2}\right)$, chloride $\left(\mathrm{CdCl}_{2}\right)$, or sulfate $\left(\mathrm{CdSO}_{4}\right)$ (Kabata-Pendias, 2001). According to several reports, an estimated 300000 tons 
of cadmium a year are released to the environment (Kabata-Pendias, 2001; Nava-Ruiz \& Mendez-Armenta, 2011).

The first report of cadmium in the Yucatan Peninsula was published back in 1987 (RojasMinguer \& Morales-Vela, 2002). The report found that this substance has high persistence and wide distribution in underground water in the Yucatan Peninsula, to the point that concentrations ranging from 0.02 to $0.062 \mathrm{mg} / \mathrm{l}$ have been reported. These values exceed the maximal permissible limit of cadmium concentrations at sea $(0.005 \mathrm{mg} / \mathrm{l})$, set by the current Mexican legislation (NOM-127-SSA1-1994, 1994). It also violates the Ley Federal de Derechos en Materia de Agua (Federal Law on Water Rights) (2016) which suggests concentrations of $0.01 \mathrm{mg} / \mathrm{l}$ in water and $0.1 \mathrm{mg} / \mathrm{l}$ for protection of aquatic life as a limit (PachecoÁvila, Cabrera-Sansores, Barcelo-Quintal, \& Pacheco-Perera, 2011).

Regrettably, there is no continuous monitoring for the variations of cadmium concentration in water, sediment, and biota. Therefore, the risks of cadmium pollution for aquatic biota are unknown, which has become a serious problem because cadmium and other metals are persistent, toxic, and bio-accumulate (Mackay, Celsie, Powell, \& Parnis, 2018). For instance, cadmium's acute toxicity, expressed as lethal concentration $50\left(\mathrm{LC}_{50}\right)$ in zooplankton, ranges between 0.01 and $39 \mathrm{mg} / \mathrm{l}$. The lowest $\mathrm{LC}_{50}$ value reported for cadmium in rotifers from freshwater strains of Mexico City, such as Brachionus calyciflorus, is $0.01 \mathrm{mg} / \mathrm{l}$ (Sarm, Martínez-Jerónimo, Ramírez-Pérez, \& Nandini, 2006), while the highest value is for Brachionus plicatilis (Snell, Moffat, Janssen, \& Persoone, 1991).

Regarding the toxicity of cadmium for oligochaetes, Neto, Moreira, Dos Santos Lima, Daam and Rocha (2019) reported that, for $96 \mathrm{~h}$ of exposure, the LC50 of cadmium chloride is 627 and $364 \mu \mathrm{g} / \mathrm{L}$ for Allonais inaequalis and Dero furcatus respectively. This shows that the latter species is almost twice as sensitive to this metal as A. inaequalis. However, no reports of morphological alterations induced by cadmium exposure in rotifers and oligochaetes exist. Therefore, a study of this kind is necessary to have a better understanding of this metal's hazardous effects on invertebrate communities.

For that reason, the present study is the first to show that cadmium induces morphological alterations in species of rotifers (Philodina cf roseola) and necrosis in oligochaetes (Aeolosoma hemprichi) at concentrations below the $\mathrm{LC}_{50}$, within an exposure time of less than $24 \mathrm{~h}$. This investigation opens the door to potentially using these two native species as bio-indicators of cadmium pollution. Our interest is to help generate information for the protection of water and biological resources and to help determine its vulnerability.

Currently, there are 58 reports of cadmium in water and 16 reports in tissues of aquatic organisms in the Yucatan Peninsula (Pacheco-Ávila et al., 2011; Rojas-Minguer \& Morales-Vela, 2010; Avelar et al., 2013; Solís et al., 2008; \& Tah-Euan, 2009). However, there is still a lack of information regarding the sensitivity of aquatic species to cadmium. In this research, we experimentally observed the deformations associated to acute exposure to cadmium. For the purpose of this study, we assumed that deformations were physiological responses of molecular, cellular tissue and biochemical damage before lethality is induced by high doses in short times (Alvarado-Flores, Rico-Martínez, Adabache-Ortiz, \& Silva-Briano, 2015; Lavoie et al., 2017).

\section{MATERIALS AND METHODS}

Collection and cultivation in laboratory: Organisms were collected from June to October 2017 in two dolines (cenotes) in northeastern Quintana Roo. Temperature $\left({ }^{\circ} \mathrm{C}\right)$, $\mathrm{pH}$, and electrical conductivity $(\mathrm{mS} / \mathrm{cm})$ were measured in situ by means of a previously calibrated multi-parametric probe Condutronic PC18. Organisms were collected using a Wisconsin net with a $55-\mu \mathrm{m}$ mesh aperture. Three drags were performed to collect a final volume of $250 \mathrm{ml}$ per sample. Two samples per doline were collected. Specialized dichotomic and 
pictorial keys were used for species identification (Fontaneto \& Ricci, 2004; Fontaneto, De Smet, \& Melone, 2008; Brinkhurst, 1971).

The species identified as Philodina $c f$ roseola was isolated from the locality named "La Victoria" (2059'18.8" N \& 87¹2'08.2" W), a doline with a maximum depth of 20 meters. More details related to identifications and photographs of the specimen are added as an appendix (Digital Appendix 1, Digital Appendix 2, Digital Appendix 3) to this manuscript. This location has a rocky bottom with unsolidified sediment and mostly arboreal and herbaceous vegetation. The temperature at the time of collection was $27.2^{\circ} \mathrm{C}$ with an electrical conductivity of $0.8 \mathrm{mS} / \mathrm{cm}$ and a $\mathrm{pH}$ of 7.3 . This site is also used for tourism and production of tilapia for human consumption. On the other hand, A. hemprichi was isolated from a cave-type urban doline named "Chac Mool (2109'29.0” N \& 86 52'14.6”'W). This zone has unsolidified sediments: the water had a temperature of $24.5{ }^{\circ} \mathrm{C}$, electrical conductivity of $1.2 \mathrm{mS} / \mathrm{cm}$ and $\mathrm{pH}$ of 8.53 .

The isolation of organisms was carried out in 24-well polystyrene plates (Costar) in which one individual was placed per well in a final volume of $1 \mathrm{~mL}$ reconstituted water, recommended by the USEPA (1985). This EPA medium contains $96 \mathrm{mg} / \mathrm{l}$ of $\mathrm{NaHCO}_{3}, 60$ $\mathrm{mg} / \mathrm{l}$ of $\mathrm{CaSO}_{4} \cdot 2 \mathrm{H}_{2} \mathrm{O}, 60 \mathrm{mg} / \mathrm{l}$ of $\mathrm{MgSO}_{4} \cdot 7$ $\mathrm{H}_{2} \mathrm{O}$, and $4 \mathrm{mg} / \mathrm{l}$ of $\mathrm{KCl}$, $\mathrm{pH}$ of 7.5 , hardness of 80-100 and alkalinity of 57-64 (expressed as $\mathrm{mg} \mathrm{CaCO}_{3} / \mathrm{L}$ ) (USEPA, 1985). Additionally, a medium from the collection site - filtered with a 55- $\mu \mathrm{m}$ aperture mesh - was added.

P. cf roseola was fed only with the algae Nannochloropsis oculata (strain LB2164 of the University of Texas Collection). It was cultivated adding a MicroGrow medium (F2 modified, Florida Aqua Farms) into a reconstituted water medium. Meanwhile, A. hemprichi was fed with $N$. oculata and lemon tree leaves cut into $1 \mathrm{~cm}$ squares in three different treatments: (1) microalga at a concentration of $3 \times 10^{6}$ cells/ $\mathrm{ml}$; (2) lemon tree leaves; and (3) microalga at a concentration of $3 \times 10^{6}$ cells $/ \mathrm{ml}+$ lemon tree leaves. All the experiments used one organism/
$\mathrm{mL}$ for 15 days with three replicates. Both species were incubated in a bio-climatic cabinet (Thermo Scientific) at a temperature of $25 \pm$ $2{ }^{\circ} \mathrm{C}$, with a photoperiod of 12 hours of light and 12 hours of darkness. After 15 days, the organisms with the best growth per well were transferred to petri dishes in a volume of 10 $\mathrm{mL}$ and reproduced in a monoclonal way over 2 months in preparation for the cadmium exposure experiments.

We used these two native species from Quintana Roo, Mexico to estimate the hazard to aquatic biota because they have the potential to become model organisms for ecotoxicology and genotoxicology in assays and for their importance in aquatic ecosystems (Song \& Chen, 2009; Snell, Johnston, \& Matthews, 2017). Additionally, rotifers and oligochaetes clonal reproduction permits individual genotypes to be cultured for many generations in the lab.

Acute toxicity: Deionized water was used for all analytical work; for acute toxicity testing, we utilized a standard solution of cadmium for atomic absorption $\left(1000 \mathrm{Cd}^{+2} \mathrm{mg} / \mathrm{l}\right.$ in $\mathrm{HNO}_{3}$, Sigma-Aldrich). The cadmium standard was diluted with freshwater medium to prepare the following nominal exposure concentrations: $0.05,0.1,0.3,0.5,0.6,0.75,0.8,1.0,2.0$, $3.0,5.0$, and $10.0 \mathrm{mg} / \mathrm{l}(\mathrm{pH}$ of dilutions was 7). The determination of cadmium in the 10 $\mathrm{mg} \mathrm{Cd} / \mathrm{L}$ stock solution was performed using atomic absorption with a PE Analyst 800 Spectrometer with (1) transversely heated graphite furnace; (2) longitudinal Zeeman-effect background correction; and (3) AS-60 auto-sampler with a detection limit of $0.001 \mathrm{mg} / 1$, analyzed in duplicate $(9.398 \pm 0.089 \mathrm{mg} / \mathrm{l})$. All materials used for cadmium analysis were soaked in 10 $\%$ nitric acid, rinsed with deionized water, and dried before use. Analytical spike recovery was 80 to $100 \%$ and relative percent difference between replicate analyses of subsamples was less than $10 \%$.

Secondly, Philodina of roseola experiments were performed with neonates younger than $24 \mathrm{~h}$. The acute testing was carried out 
as follows: ten neonates were placed in a final volume of $1 \mathrm{ml}$ for each concentration in 24-well polystyrene plates $\left(\operatorname{Costar}^{\circledR}\right)$. They were incubated in the bio-climatic cabinet for 24 hours. Six replicas with six repetitions for each concentration were carried out. At the end of the acute testing, the morphology of the intoxicated organisms was compared to the control organisms and the number of organisms with morphological alterations by concentration was calculated. The standard solution was commercial $1000 \mathrm{mg}$ of $\mathrm{Cd} / \mathrm{L}$ in $\mathrm{HNO} 3$ (Sigma Aldrich). Thus, the experiments were performed in acidic conditions. Tests were considered valid only when mortality in the EPA medium was less than $10 \%$. We included a negative control composed only by deionized water and $0.2 \% \mathrm{HNO}_{3}(\mathrm{pH} 6)$ in order to assess possible adverse effects on the cuticle of $A$. hemprichi over a 24-hour exposure.

The $\mathrm{LC}_{50}$ value was calculated using regression with probit units and the logarithm of each toxicant concentration by the software Statistica ${ }^{\circledR}$ Version 7. The NOEC (not observed effect concentration) and LOEC (lowest observed effect concentration) values were calculated with a one-way variance analysis (ANOVA) and Duncan post hoc tests run in Statistica ${ }^{\circledR}$ Version 7.

On the other hand, one organism was placed on each well of a 24-well plate for acute toxicity testing with $A$. hemprichi. Therefore, a total of 45 organisms for the control and 56 organisms for each $\mathrm{Cd}$ exposure concentration $(0.1,0.25,0.75,1.0,3.0,5.0$, and $7.0 \mathrm{mg} / \mathrm{l})$ were used. Exposure time was 30 minutes, based on previous results observed for the same species exposed to the metalloid arsenic (AlvaradoFlores et al., 2018; unpublished data). At the end of the exposure, the number of organisms with morphological alterations in their cuticle were recorded. It also was described if they presented superficial darkening and partial or total disintegration (Fig. 2).

Cadmium bio-concentration in Aeolosoma hemprichi: Additionally, an analysis of in vivo intracellular cadmium uptake in
A. hemprichi using Leadmium Green AM was performed. One group of $30 \mathrm{~A}$. hemprich $i$ was used as a control without $\mathrm{Cd}$. The other groups of 30 oligochaeta specimens were treated with $0.1,0.5$, and $1.0 \mathrm{mg} / \mathrm{l} \mathrm{Cd}$ for $30 \mathrm{~min}$. The experiments took place in a 24 -well polystyrene plate with a final volume of $1 \mathrm{ml}$ in USEPA medium. Finally, we analyzed all oligochaeta in each group following the protocol of AlvaradoFlores, Rico-Martínez, Ventura-Juárez, SilvaBriano and Rubio-Franchini (2012).

Fluorescence was determined with an excitation spectrum of $450-490 \mathrm{~nm}$ and an emission barrier of $515 \mathrm{~nm}$. Photographs were taken with the AxioCam ICC1 camera (Software SE64ReL 4.8 Inc 2003) coupled to an Axio Zeiss, Imager A2 microscope using AxioVision software. $\mathrm{Cd}$ intracellular analysis in Philodina cf roseola was not assessed because there is existing data for other rotifer species (Alvarado-Flores et al., 2012; Alvarado-Flores \& Rico-Martínez, 2017).

After the place of $\mathrm{Cd}$ bio-concentration in the oligochaeta was identified, twenty organisms were placed in an Eppendorf tube and fixed for 2 hours with $4 \%$ paraformaldehyde followed by 2 hours with $2 \%$ osmium tetroxide at $4{ }^{\circ} \mathrm{C}$. They were washed with distilled water and dehydrated in graduated alcohols from 50 to $100 \%$. Later, the organisms were placed in a $0.5-\mu 1$ Eppendorf tubes in LR-White resin to harden for 24 hours at $56{ }^{\circ} \mathrm{C}$. Twohundred-nanometer histological sections were made using an ultra-microtome (Ultracut $\mathrm{R}$ Leica $\left.{ }^{\circledR}\right)$. Their sections were stained with tolonium chloride and photographed with a Cool Snap Pro camera coupled to a Zeiss Axioscop 40 microscope.

For the photographs in the electron-scanning microscope, 20 organisms were placed in an Eppendorf tube and fixed for 2 hours with $4 \%$ formaldehyde and 2 hours with $2 \%$ osmium tetroxide at $4{ }^{\circ} \mathrm{C}$. Then, samples were dehydrated with graduated alcohol (50-100 \%) and moisture was eliminated using a Tousimis critical point dryer with liquid $\mathrm{CO}_{2}$. Finally, they were coated in gold using a DESK II 
camera and photographed with a JEOL LV 5000 MEB microscope.

\section{RESULTS}

Organism cultivation: As pointed out before, two zooplankton species from Quintana Roo, México, were isolated: Philodina of roseola and $A$. hemprichi. Experiments began after a two-month adaptation period. The net growth of rotifer $P$. cf roseola in laboratory cultures averaged $93.75 \pm 48.06$ female eggs and $21.41 \pm 11.95$ male eggs in a final volume of $2 \mathrm{ml}$ from an initial density of 10 organisms per well. The largest number of $A$. hemprich $i$ organisms was in the culture that included microalga and lemon tree leaves over a period of 15 days. This combination produced 86.33 \pm 15.93 females from an initial density of 10 organisms in $2 \mathrm{ml}$ (Table 1).

Cadmium toxicity: The $\mathrm{LC}_{50}$ value for P. cf roseola was $0.7 \mathrm{mg} / \mathrm{l}\left(\mathrm{LC}_{50}=0.65 \mathrm{mg} / \mathrm{l}\right.$ in real concentration). We also obtained an
$\mathrm{R}^{2}$ of 0.8 , with $95 \%$ confidence limits for the $\mathrm{LC}_{50}$ value of $0.65-0.75$. On the other hand, the NOEC value was $0.3 \mathrm{mg} / \mathrm{l}$, and the LOEC value was $0.5 \mathrm{mg} / \mathrm{l}$. For $A$. hemprichi, the $\mathrm{LC}_{50}$ value was $3.38 \mathrm{mg} / 1\left(\mathrm{LC}_{50}=3.17 \mathrm{mg} / \mathrm{l}\right.$ in real concentration); the $\mathrm{R}^{2}$ value was 0.93 with 95 $\%$ confidence limits for the $\mathrm{LC}_{50}$ value of 2.76 4.01. The NOEC value was $0.5 \mathrm{mg} / 1$; nevertheless, the LOEC value could not be established.

The toxicity values in the rotifer corresponded to a 24-hour exposure, whereas, in the oligochaete, they corresponded to a 30-minute exposure. The threshold concentration at which deformations appeared in rotifers was $0.3 \mathrm{mg} / \mathrm{l}$ (24 h) was $0.5 \mathrm{mg} / 1$ (30 minutes) for $A$. hemprichi. In $P$. cf roseola, 60 organisms presented deformations in the foot, head, and the middle part of the trunk (Fig. 1A, Fig. 1B, Fig. 1C1, Fig. 1C2, Fig. 1C3, Fig. 1C4, Fig. 1C5, Fig. 1C6). In concentrations, on the other hand, of $0.3 \mathrm{mg} / 1(0.282 \mathrm{mg} / \mathrm{l}$, real concentration) $\mathrm{Cd}, 0.76 \%$ of organisms had deformations; in $0.5 \mathrm{mg} / \mathrm{l}(0.47 \mathrm{mg} / \mathrm{l}$, real concentration), 23.4 $\%$ had deformations; and in $1.0 \mathrm{mg} / 1,55.9 \%$ had deformations.

TABLE 1

Aeolosoma hemprichi intrinsic growth with alga Nannochloropsis oculata and lemon tree leaves

TABLA 1

Crecimiento intrínseco de Aeolosoma hemprichi con el alga Nannochloropsis oculata y hojas de árbol de limón

\begin{tabular}{cccc} 
Day & $\begin{array}{c}\text { Treatment } \\
\text { Average number of organisms } \\
\text { in environment with } 3 \times 10^{6} \text { cells } / \mathrm{ml}\end{array}$ & $\begin{array}{c}\text { Average } \\
\text { with } 1 \mathrm{~cm}^{2} \text { of lemon tree leaf }\end{array}$ & $\begin{array}{c}\text { Average number of organisms with } \\
3 \times 10^{6} \text { cells } / \mathrm{ml}+1 \mathrm{~cm}^{2} \text { lemon tree leaf }\end{array}$ \\
1 & 1 & 1 & 1 \\
2 & 1 & 1 & 1 \\
3 & 1 & $1.08 \pm 0.28$ & 1 \\
4 & 1 & $1.08 \pm 0.28$ & 1 \\
5 & 1 & $1.08 \pm 0.28$ & $1.5 \pm 0.70$ \\
6 & 2 & $1.33 \pm 0.77$ & $2 \pm 1.41$ \\
7 & $1.5 \pm 0.7$ & $1.58 \pm 0.90$ & $3 \pm 1.41$ \\
8 & $1 \pm 1.41$ & $1.6 \pm 1.15$ & $3.5 \pm 0.70$ \\
9 & $1.5 \pm 2.12$ & $2 \pm 1.27$ & $4 \pm 2.82$ \\
10 & $2 \pm 2.82$ & $1.91 \pm 1.37$ & $5.5 \pm 4.94$ \\
11 & $1.5 \pm 2.12$ & $2.83 \pm 2.03$ & $7 \pm 5.6$ \\
12 & $2.5 \pm 3.53$ & $3 \pm 2.44$ & $8.5 \pm 4.94$ \\
13 & $3.5 \pm 4.94$ & $2.5 \pm 2.39$ & $7.5 \pm 3.53$ \\
14 & $3.5 \pm 4.94$ & $2.66 \pm 2.46$ & $9.5 \pm 9.19$ \\
15 & 0 & $2.83 \pm 3.48$ & $10.5 \pm 6.36$ \\
\hline
\end{tabular}




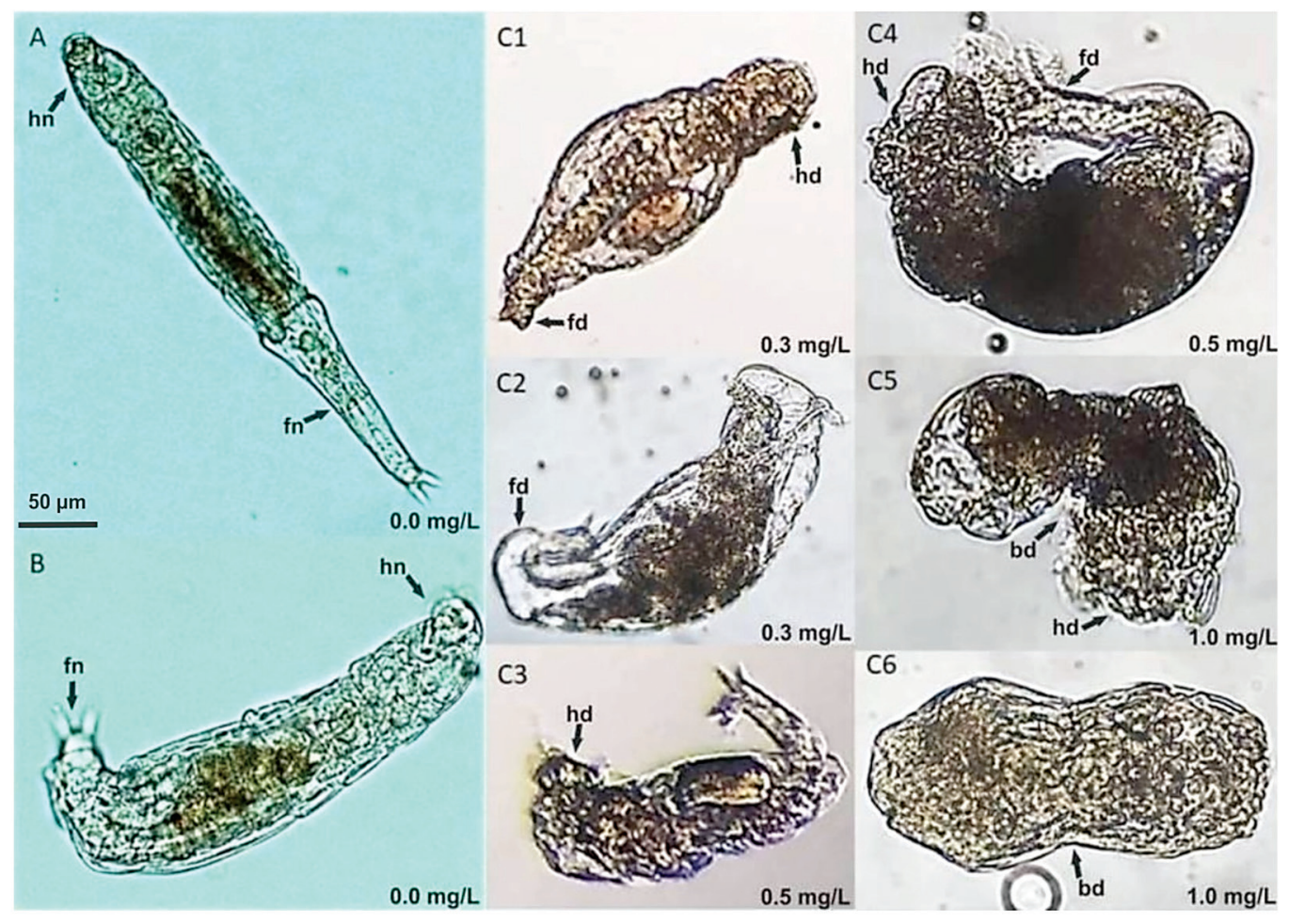

Fig. 1. Philodina cf roseola deformations from cadmium exposure. A-B. Control specimens with no deformations in body, foot, or head. C1-C6. Organisms with deformations at various cadmium concentrations: head deformation (hd), foot deformation (fd), deformation in the middle part of the body (bd), normal foot (fn), or normal head (hn).

Fig. 1. Deformaciones en Philodina cf roseola por exposición a cadmio. A-B. Especímenes control sin deformaciones en cuerpo, pie, o cabeza. C1-C6. Organismos con deformaciones a diferentes concentraciones de exposición: deformación en cabeza (hd), deformación en pie (fd), deformación en la parte media del cuerpo (bd), pie normal (fn), o cabeza normal (hn).

The percentage of morphological alterations observed in A. hemprichi is broken down in Table 2. Exceptionally, structural damage in the oligochaeta occurred at 30 minutes and total disintegration was observed in concentrations of $3.0(2.81 \mathrm{mg} / \mathrm{l}$, real concentration) and 7.0 (6.57 mg/l, real concentration) $\mathrm{mg} / \mathrm{l} \mathrm{Cd}$ at 24 hours. For this reason, exposure tests were carried out with a cadmium-free control in a solution of $0.2 \% \mathrm{HNO}_{3}$ dissolved in the reconstituted medium recommended by the USEPA (1985). We also observed that a $0.2 \% \mathrm{HNO}_{3}$ did not have adverse effects on the cuticle of $A$. hemprichi over a 24-hour exposure.

We also analyzed the route of entry and bio-concentration of cadmium using Leadmium Green, an intracellular fluorescent marker for cadmium. Its main route of entry was digestion and it bio-concentrated in the anterior and posterior intestine after 30 minutes of exposure at $0.1 \mathrm{mg} / \mathrm{l}$ or the equivalent concentration of $0.094 \mathrm{mg} / \mathrm{l}$ (Fig. 2D). Other morphological changes occurred at $0.5(0.47 \mathrm{mg} / \mathrm{l}$, real concentration) $\mathrm{mg} / \mathrm{l}$. In Figure 2, the composition of the internal digestive system of the oligochaeta is shown in detail; histological cuts and scanned photographs are displayed (Fig. 2A, Fig. 2B, Fig. 2C, Fig. 2D, Fig. 2E).

\section{DISCUSSION}

Cadmium morphological alterations occured in P. cf roseola and A. hemprichi after 24 hours and 30 minutes, respectively. In the 
TABLE 2

Death by necrosis from cadmium exposure for Aeolosoma hemprichi

TABLA 2

Muerte por necrosis de Aeolosoma hemprichi por exposición al cadmio

\begin{tabular}{cccc} 
Cadmium $(\mathrm{mg} / \mathrm{L})$ & Percentage of necrotic death $(\mathrm{t}=30 \mathrm{~min})$ & Coefficient of variation & $\mathrm{n}$ \\
0 & 0 & 0 & 45 \\
0.1 & 0 & 0 & 56 \\
0.25 & 0 & 0 & 56 \\
0.5 & $5.36 \pm 22.72$ & 424.12 & 56 \\
0.75 & $10.71 \pm 31.21$ & 291.29 & 56 \\
1 & $16.07 \pm 37.06$ & 230.59 & 56 \\
3 & $21.15 \pm 40.09$ & 189.51 & 52 \\
5 & $89.28 \pm 31.21$ & 34.95 & 56 \\
7 & 100 & 0 & 56 \\
\hline
\end{tabular}

$\mathrm{n}=$ the total number of organisms exposed per treatment $(\mathrm{N}=489) / \mathrm{n}=$ total de organismos expuestos por tratamiento $(\mathrm{N}=489)$.

former, morphological changes began at a cadmium concentration of $0.3 \mathrm{mg} / 1(0.282 \mathrm{mg} / \mathrm{l}$, real concentration), whereas in the latter they appeared at $0.5 \mathrm{mg} / 1(0.47 \mathrm{mg} / \mathrm{l}$, real concentration). After 24 hours, both species showed high sensitivity in comparison to the chronic (5 days) exposure to other organic toxins reported in other studes, like the fungicide vinclozolin in Brachionus calyciflorus, which caused severe morphological alterations in its body (Alvarado-Flores et al., 2015). In our study, the main structural damages occurred in the organisms' cuticle.

The main reasons to such response can be attributed to the following: (1) first, oligochaetes' epidermis is a soft cuticle and absorbs nutrients and light-weight molecules (Jamieson, 1992); (2) aquatic invertebrates' cuticles create a complex osmotic barrier for $\mathrm{Na}^{+}, \mathrm{Cl}^{-}$, and other elements such as $\mathrm{N}, \mathrm{Ca}, \mathrm{K}$, and $\mathrm{Si}$ (Péqueux, 1991). Finally, (3) rotifers' lorica possesses an integument or an intrasyncytial layer, which can be of two types: the hard lorica (loricated rotifers) and soft lorica (iloricated rotifers), which contains disulfide and keratin bridges together with lysine, glutamate, and aspartic acid, permitting enhanced bio-accumulation of metals (Kleinow, 1993; Yu \& Cui,
1997). Therefore, the cuticle is associated with organic and inorganic substances.

It is possible that toxicants that bio-concentrate in these organisms modify the cuticle's structural integrity over short periods of acute exposure in organisms with a soft cuticle, whereas in hard-cuticle organisms, it can only happen in chronic conditions (Alvarado-Flores et al., 2012; Juárez-De La Rosa et al., 2015; Hernández-Ruiz, Alvarado-Flores, RubioFranchini, Ventura-Juárez, \& Rico-Martínez, 2016; Alvarado-Flores et al., 2017). Thereby, these substances alter their reproductive, behavioral, and structural functions. For example, the cuticle of Mytlus galloprovincialis is hard; however, when certain essential elements such as $\mathrm{Ca}$ and $\mathrm{Fe}$ are removed, its structural integrity is reducing by $50 \%$ (Holten-Andersen et al., 2009).

On the other hand, when metals - such as $\mathrm{Cu}, \mathrm{Zn}$, and $\mathrm{Pb}$ - accumulate in diatoms, morphological deformations in frustules and ornamentations increase (Pandey, Kumar, Yadav, Rai, \& Gaur, 2014). These kinds of changes are an indicator of polluted environments since shifts in shape, ornamentation, and striate are the result of the combination of cellular and genetic changes regulated by environmental factors (Lavoie et al., 2017). For example, 

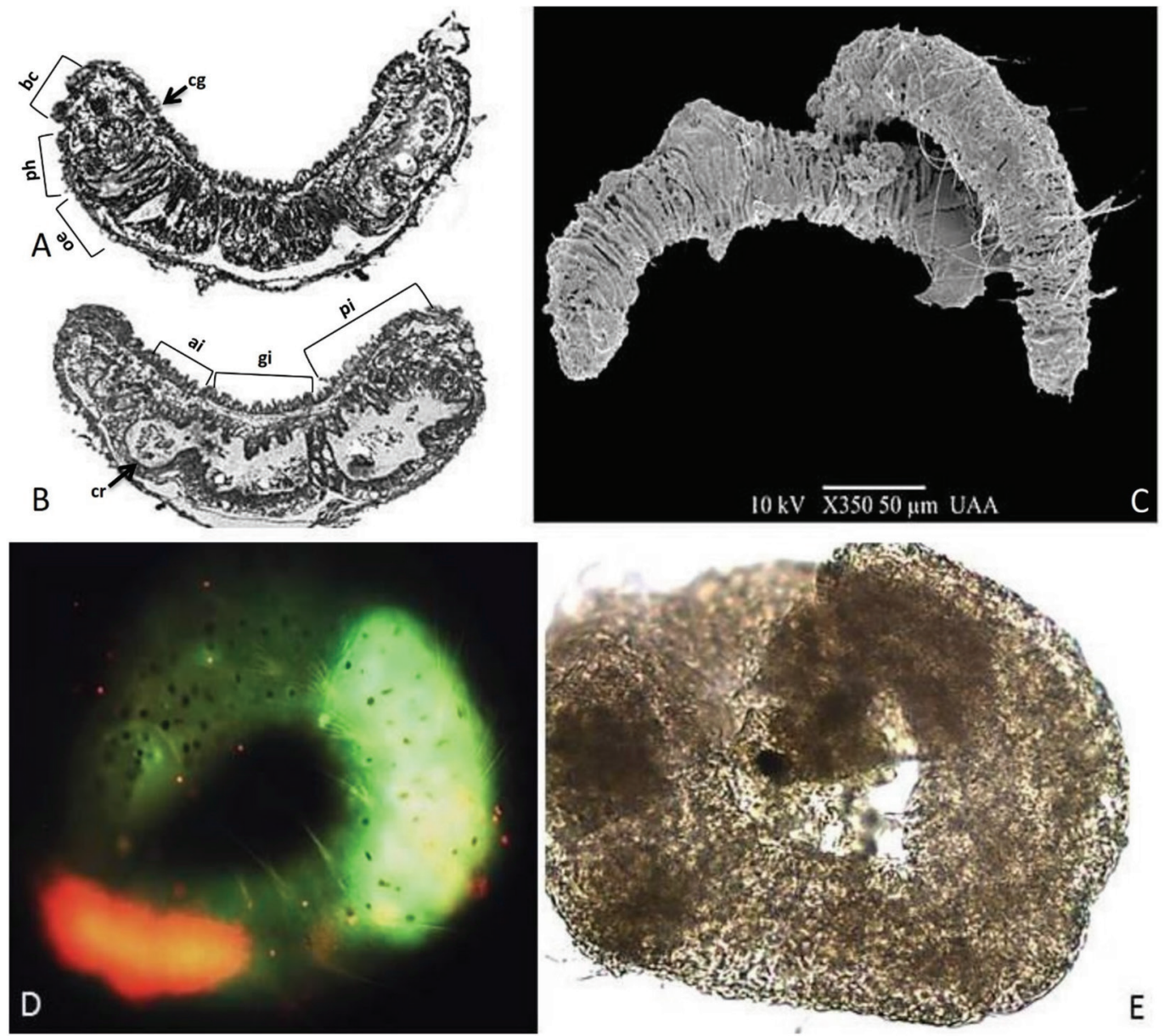

Fig. 2. A-B. Histologic cuts of Aeolosoma hemprichi in the dorsoventral position: the alimentary canal is composed of the buccal cavity (bc), pharynx (ph), esophagus (oe), calciferous glands (cg), crop (cr), gizzard (gi), anterior intestine (ai), and posterior intestine (pi) that tapers to the anus. C. Habitus of $A$. hemprichi, SEM photograph. D. Cadmium intracellular detection using Leadmium Green, exposure time of 30 minutes with $0.1 \mathrm{mg} / 1$ cadmium. E. A. hemprichi dead from necrosis, exposure time 30 minutes, with $0.5 \mathrm{mg} / 1$ cadmium.

Fig. 2. A-B. Cortes histológicos de Aeolosoma hemprichi en posición dorso ventral: el canal alimentario está compuesto por una cavidad bucal (bc), la faringe (ph), esófago (oe), glándulas calcíferas (cg), buche (cr), molleja (gi), intestino anterior (ai) e intestino posterior (pi) que se estrecha hasta el ano. C. Hábito de A. hemprichi, fotografía MEB. D. Detección intracelular de cadmio usando Leadmium Green, tiempo de exposición $30 \mathrm{~min}$, a $0.1 \mathrm{mg} / 1$ cadmio, E. Muerte de A. hemprichi por necrosis, tiempo de exposición 30 minutos a $0.5 \mathrm{mg} / 1$ de cadmio.

a cadmium concentration of $0.0426 \pm 0.0042$ $\mathrm{mg} / \mathrm{l}$ over seven days produces morphological alterations and a decrease in the expression of genes related to $\mathrm{Si}$, which is involved in the formation of the frustule in the diatom Nitzchia palea (Tiam, Lavoie, Doose, Hamilton, \& Fortin, 2018).
Many researchers have proposed that morphological alterations depend on concentration, time of exposure and the toxicant's route of entry, which in rotifers and oligochaetes is primarily digestion. According to our previous results, lead entry takes place quickly: 30 minutes for $A$. hemprichi (oligochaetes) 
and between 12 and 18 hours for the rotifers $\mathrm{Bra}$ chionus calyciflorus and Lecane quadridentata (Alvarado-Flores et al., 2012; Alvarado-Flores et al., 2017). We suggest that morphological alterations in Philodina cf roseola are related to anhydrobiosis, which is induced by stress from acute exposure to cadmium. This is a mechanism of survival, dispersion, and evolution in Bdelloidea: the body encysts and biochemical and physiological disintegration occurs (King, Ricci, Schonfeld, \& Serra, 2005).

It is likely that some toxicants, as demonstrated by our results with cadmium, induce this mechanism. Thus, cadmium can be a strong inducer of genetic expression in exposed populations. The expression of genes as a cadmium detoxification mechanism has been reported for organisms adapted to the presence of this substance, albeit in those organisms that lack this response, a decrease in the expression of genes involved in the cuticle's structural integrity and food assimilation has been observed (Roelofs et al., 2009).

On the other hand, A. hemprichi died from damage to its epidermis, an adverse effect mediated from the inside out. Its total disintegration occurred at $3.0(2.81 \mathrm{mg} / \mathrm{l}$, real concentration) to $7.0 \mathrm{mg} / \mathrm{l}(6.57 \mathrm{mg} / \mathrm{l}$, real concentration) $\mathrm{Cd}$ after $24 \mathrm{~h}$ of exposure. It was observed that this species quickly responds to cadmium exposure, which makes him a perfect specimen for studies on damage mechanisms mediated by metals and other toxicants. In fact, it is common to find $A$. hemprichi in residual water from treatment plants, and due to its biological and ecological characteristics, it can be a good indicator of changes in the concentrations of heavy metals and xenobiotics present in aquatic environments and water treatment plants (Kuniyasu, Hayashi, Inamori, \& Sudo, 1997; Song \& Chen 2009; Falconi, Gugnali, \& Zaccanti, 2015). For instance, a study in Espirito Santo Bay, Brazil, reported deformations in the copepod Acartia lilljeborgi in places with domestic wastewater discharges (Oliveira-Dias, 1999).

To sum up, cadmium produces morphological alterations in the cuticle and epidermis of the class Bdelloidea rotifers and oligochaetes of the family Aeolosomatidae. The morphological alterations depended on the hardness of the rotifers' cuticle, time of exposure, and cadmium concentration. Due to their environment and sensitivity to toxicants, both native species have the potential of being used in studies regarding structural damage from metal exposure. Morphological alterations in the rotifers with a hard cuticle were detected in the generations descended from the cohort exposed to the toxicants, whereas in organisms with a soft cuticle, alterations were observed in the exposed cohort. Therefore, according to our results and previous evidence (Snell et al., 2017; Neto et al., 2019), we believe that both species are good candidates as sentinel species for ecotoxicological assessments, specifically for cadmium toxicity, bioaccumulation and biomagnification.

Finally, we concluded that the concentrations of cadmium in the waters of the Yucatan Peninsula (from 0.02 to $0.062 \mathrm{mg} \mathrm{Cd} / \mathrm{l}$ ) exceed the maximum permissible limits allowed by national and international legislation (from 0.005 to $0.1 \mathrm{mg} \mathrm{Cd} / \mathrm{l}$ ). Thus, according to our results, there exists a high risk to the aquatic biota (measured as induced morphological effects) at environmental concentrations higher than the maximum permissible limit. In addition, it is important to stress that cadmium must be bioavailable before its bioacumulation and final biomagnification (ATSDR, 2016). For instance, cadmium salts (cadmium chloride, cadmium sulfate and cadmium nitrate) are water soluble, but other insoluble components can become more soluble by interaction with acids, light or oxygen (ATSDR, 2016).

The Yucatan Peninsula is mainly calciumcarbonate water; however, reductive conditions in sulfate-rich waters in some coastal areas (Sánchez-Sánchez, Álvarez-Legorreta, Pacheco-Ávila, González-Herrera, \& CarrilloBribiezca, 2015) can provide acidic conditions that could mobilize cadmium otherwise not available. We advocate prioritizing ecotoxicology studies using local/native species as bio-indicators of adverse effects of cadmium, 
in addition to its environmental quantification in order to obtain an integrative risk assessment in the Yucatan Peninsula as an example of karstic environment.

Ethical statement: authors declare that they all agree with this publication and made significant contributions; that there is no conflict of interest of any kind; and that we followed all pertinent ethical and legal procedures and requirements. All financial sources are fully and clearly stated in the acknowledgements section. A signed document has been filed in the journal archives.

\section{ACKNOWLEDGMENTS}

This work was supported by CONACYT's Program Cathedra from Mexico, who founded the current study: Project No. 2944. The authors are grateful to Cinthya Denisse Grimaldo Hérnandez, Ailem Marin Chan, and Isidoro Rubio-Franchini for technical support; Javier Ventura Juárez, Marcelo Silva-Briano, and Aracely Adabache-Ortiz for supporting with the MEB photographs; and Alejandra Sofía Sánchez Ávila for her technical support in the A. hemprichi histological cuts. D,P-Y received a grant from the National Council of Science and Technology (CONACYT), México, No CVU 886276.

\section{RESUMEN}

Cadmio y alteraciones morfológicas en el rotífero Philodina cf. roseola (Bdelloidea: Philodinidae) y el gusano Aeolosoma hemprichi (Annelida: Aeolosomatidae). El cadmio es un metal tóxico que produce deformaciones en el zooplancton y es considerado un peligro para el ambiente y la vida acuática. Por ello, utilizamos dos especies de zooplancton nativas de Quintana Roo, México para obtener datos sobre la toxicidad de cadmio, incluyendo la concentración umbral para alteraciones morfológicas observables y el porcentaje de organismos con alteraciones morfológicas en las concentraciones de exposición. Utilizamos el rotífero Philodina cf roseola y el oligoqueto Aeolosoma hemprichi, ya que ambos se alimentan del alga Nannochloropsis oculata. Seguidamente, ambas especies de animales fueron expuestas a un rango de concentración de cadmio de 0.05 (0.047 mg/l, concentración real) a
$10.0 \mathrm{mg} / 1$ (9.398 mg/l, concentración real) durante $24 \mathrm{~h}$. El $\mathrm{CL}_{50}$ para cadmio en P. cf roseola fue de $0.7 \mathrm{mg} / 1(0.65$ $\mathrm{mg} / \mathrm{l}$, concentración real), mientras que en $A$. hemprichi fue de $3.38 \mathrm{mg} / 1$ ( $3.17 \mathrm{mg} / \mathrm{l}$, concentración real). El cadmio a concentraciones de $0.5 \mathrm{mg} / 1$ ( $0.47 \mathrm{mg} / 1$, concentración real $)$ y exposición menor a $24 \mathrm{~h}$, por un lado, indujo alteraciones morfológicas en la lorica de los rotíferos, deformaciones del pie y constricciones en la parte media del cuerpo. En oligoquetos, por otro lado, observamos daños en la epidermis. La concentración umbral donde las deformaciones aparecieron en rotíferos fue $0.3 \mathrm{mg} / 1(0.28 \mathrm{mg} / 1$, concentración real) a las $24 \mathrm{~h}$, mientras que en oligoquetos fue a 0.5 $\mathrm{mg} / \mathrm{l}$ ( $0.47 \mathrm{mg} / \mathrm{l}$ concentración real) en $30 \mathrm{~min}$. Concluimos que claramente el cadmio promueve alteraciones morfológicas en organismos acuáticos, debido a la exposición directa que se añade al medio de cultivo.

Palabras clave: teratología, ecotoxicología, zooplancton, Península de Yucatán, toxicidad de metales.

\section{REFERENCES}

Alvarado-Flores, J., \& Rico-Martínez, R. (2017). Bioconcentration of lead and X-ray microanalysis with sem in the freshwater rotifer Lecane quadridentata (Rotifera: Monogonta). Polish Journal of Environmental Studies, 26, 1-4.

Alvarado-Flores, J., Rico-Martínez, R., Adabache-Ortiz, A., \& Silva-Briano, M. (2015). Morphological alterations in the freshwater rotifer Brachionus calyciflorus Pallas 1766 (Rotifera: Monogononta) caused by vinclozolin chronic exposure. Ecotoxicology, 24, 915-925.

Alvarado-Flores, J., Rico-Martínez, R., Ventura-Juárez, J., Silva-Briano, M., \& Rubio-Franchini, I. (2012). Bioconcentration and localization of lead in the freshwater rotifer Brachionus calyciflorus Pallas 1677 (Rotifera: Monogononta). Aquatic Toxicology, 109, 127-132.

ATSDR (Agency for Toxic Substances and Disease Registry). (2016). Draft toxicological profiles for lead and cadmium. Retrieved from https://www.atsdr.cdc.gov/ toxprofiledocs/index.html

Avelar, M., Bonilla-Heredia, B., Merino-Ibarra, M., Herrera-Silva, J. A., Ramírez, J., Rosas, H., ... Martínez, A. (2013). Iron, cadmium, and chromium in seagrass (Thalassia testidinum) from a coastal nature reserve in karstic Yucatán. Environmental Monitoring Assessment, 185(9), 7591-7603.

Bernard, A. (2008). Cadmium and its adverse effects on human health. Indian Journal of Medical Research, 128(4), 557-564.

Brinkhurst, R. O. (1971). A guide for the identification of British aquatic oligochaeta. Wareham, United Kingdom: Freshwater Biological Association. 
USEPA (U.S. Environmental Protection Agency). (1985). Methods for measuring the acute toxicity of effluents to freshwater and marine organisms. Washington D. C., United States: US Environmental Protection Agency.

Falconi, R., Gugnali, A., \& Zaccanti, F. (2015). Quantitative observation on asexual reproduction of Aeolosoma viride (Annelida, Aphanoneura). Invertebrate Biology, 134(2), 151-161.

Fontaneto, D., \& Ricci, C. (2004). Rotifera: Bdelloidea. In C. M. Yule \& H. S. Yong (Eds.), Freshwater invertebrates of the malaysian region (pp. 121-126). Kuala Lumpur, Malaysia: Academy of Science Malaysia.

Fontaneto, D., De Smet, W. H., \& Melone, G. (2008). Identification key to genera of marine rotifers worldwide. Meiofauna Marina, 16, 75-99.

Hernández-Ruiz, E., Alvarado-Flores, J., Rubio-Franchini, I., Ventura-Juárez, J., \& Rico-Martínez, R. (2016). Adverse effects and bioconcentration of chromium in two freshwater rotifer species. Chemosphere, 158 , 107-115.

Holten-Andersen, N., Mates, T. E., Toprak, M. S., Stucky, G. D., Zok, F. W., \& Waite, J. H. (2009). Metals and the integrity of a biological coating: the cuticle of mussel byssus. Langmuir, 25(6), 3323-3326.

Jamieson, B. (1992). Oligochaeta. In W. Frederick \& S L. Gardiner (Eds.), Microscopic Anatomy of Invertebrates (pp. 217-322). New York, United States: Wiley-Liss, Inc.

Juárez-De La Rosa, B. A., May-Crespo, J., QuintanaOwen, P., Gónzalez-Gómez, W. S., Yañez-Limón, J. M., \& Alvarado-Gil, J. J. (2015). Thermal analysis and structural characterization of chitinous exoskeleton from two marine invertebrates. Thermochimica Acta, 610, 16-22.

Kabata-Pendias, A. (2001). Trace elements in soils and plants. Boca Ratón, United States of America: CRC Press LLC.

King, C. E., Ricci, C., Schonfeld, J., \& Serra, M. (2005) Evolutionary dynamics of the Bdelloid and monogonont rotifer life-history patterns. Hydrobiologia, $546,55-70$.

Kleinow, W. (1993). Biochemical studies on Brachionus plicatilis: hydrolytic enzymes, integument proteins and composition of trophy. Hydrobiologia, 255/254, $1-12$.

Kuniyasu, K., Hayashi, N., Inamori, Y., \& Sudo, R. (1997). Effect of environmental factor on growth characteristic of Oligochaeta. Japanese Journal of Water Treatment Biology, 4, 207-214.

Lavoie, I., Hamilton, P. B., Morin, S., Tiam, S. K., Kahlert, M., Goncalves, S. ...Taylor, J. C. (2017). Diatom teratologies as biomarkers of contamination: are all deformities ecologically meaningful? Ecological Indicators, 82, 539-550.

Ley Federal de Derechos en Materia de Agua 2016. Recuperado el 23 de agosto, 2019 dehttps://www.gob. $\mathrm{mx} / \mathrm{cms} /$ uploads/attachment/file/105138/Ley_Federal_de_Derechos.pdf

Mackay, D., Celsie, A. K. D., Powell, D. E., \& Parnis, J. M. (2018). Bioconcentration, bioaccumulation, biomagnification and trophic magnification: a modelling perspective. Environmental Science: Processs \& Impacts, 20, 72-85.

Nava-Ruiz, C., \& Méndez-Armenta, M. (2011). Efectos neurotóxicos de metales pesados (cadmio, plomo, arsénico y talio). Archivos de Neurociencias, 16, 140-147.

Neto, G. A. J., Moreira, R. A., dos Santos Lima, J. C., Daam, M. A., \& Rocha, O. (2019). Freshwater neotropical oligochaetes as native test species for the toxicity evaluation of cadmium, mercury and their mixtures. Ecotoxicology, 28, 133-142.

Norma oficial mexicana NOM-127-SSA1-1994 "Salud ambiental, agua para uso y consumo humano-límites permisibles de calidad y tratamientos a que debe someterse el agua para su potabilización". (1994). Recuperado el 23 de agosto, 2019 de http://www. salud.gob.mx/unidades/cdi/nom/117ssa14.html.

Oliveira-Dias, C. (1999). Morphological abnormalities of Acartia lilljeborgi (Copepoda, Crustacea) in the Espírito Santo Bay (E.S. Brazil). Hydrobiologia, 394, 249-251.

Pacheco-Ávila, J., Cabrera-Sansores, A., Barcelo-Quintal, M., \& Pacheco-Perera, M. (2011). Environmental study on cadmium in groundwater in Yucatan. Springer-Verlag Berlin Heidelber, 7, 240-249.

Pandey, L. K., Kumar, D., Yadav, A., Rai, J., \& Gaur, J. P. (2014). Morphological abnormalities in periphytic diatoms as a tool for biomonitoring of heavy metal pollution in a river. Ecological Indicators, 36, 272-279.

Péqueux Et Lignon, J. (1991). Perméabilité cuticulaire et ionorégulation chez les crustacés décapodes. Cahiers De Biologie Marine, 32, 203-211.

Roelofs, D., Janssens, T. K., Timmermans, M. J., Nota, B., Mariën, J., Bochdanovits, Z., ...van Straalen, N. M. (2009). Adaptive differences in gene expression associated with heavy metal tolerance in the soil arthropod Orchesella cincta. Molecular Ecology, 18, 3227-3239.

Rojas-Minguer, A., \& Morales-Vela, B. (2002). Metales en hueso y sangre de manatíes (Trichechus manatus manatus) de la bahía de Chetumal, Quintana Roo, México. En F. J. Rosado-May, R. Romero-Mayo, \& 
J. Navarrete (Eds.), Contribuciones de la ciencia al manejo costero de la bahía de Chetumal y su área de influencia (pp. 133-142). Chetumal, México: Universidad de Quintana Roo.

Sánchez-Sánchez, J. A., Álvarez-Legorreta, T., PachecoÁvila, J. G., González-Herrera, R. A., \& Carrillo-Bribiezca, L. (2015). Caracterización hidrogeoquímica de las aguas subterráneas del sur del Estado de Quintana Roo, México. Revista Mexicana de Ciencias Geológicas, 32(1), 62-76.

Sarm, S. S. S., Martínez-Jerónimo, F., Ramírez-Pérez, T., \& Nandini, S. (2006). Effect of cadmium and chromium toxicity on the demography and population growth of Brachionus calyciflorus and Brachionus patulus (Rotifera). Journal of Environmental Science and Health Part A, 41, 543-558.

Snell, T. W., Johnston, R. K., \& Matthews, A. (2017). Freshwater toxicity testing using rehydrated Philodina sp. (Rotifera) as test animals. Environmental Toxicology, 32(10), 2267-2276.

Snell, T. W., Moffat, B. D., Janssen, C., \& Persoone, G. (1991). Acute toxicity tests using rotifers. III. Effects of temperature, strain, and exposure time on the sensitivity of Brachionus plicatilis. Environmental Toxicology and Water Quality, 6(1), 63-75.

Solís, C., Isaac-Olivé, K., Martínez, A., Lavoiser, E., \& Ruiz, R. (2008). Trace metals in the seagrass Thalassia testudinum from Mexican Caribbean coast. X-ray Spectrometry, 37, 103-106.

Song, B., \& Chen, X. (2009). Effect of Aeolosoma hemprichi on excess activated sludge reduction. Journal and Hazardous Materials, 162, 300-304.

Tah-Euan, J. E. (2009). Bioacumulación de metales pesados en mangle rojo (Rhizophora mangle) (Tesis de licenciatura). Universidad de Quintana Roo, México.

Tiam, S. K., Lavoie, I., Doose, C., Hamilton, P. B., \& Fortin, C. (2018). Morphological, physiological and molecular responses of Nitzchia palea under cadmium stress. Ecotoxicology, 27, 675-688.

Yu, J. P., \& Cui, S. J. (1997). Ultrastructure of the rotifer Brachionus plicatilis. Hydrobiologia, 358, 95-103. 